\title{
INDONESIA ADALAH NEGARA HUKUM
}

\author{
Nama Mahasiswa: Erica khairani \\ Email : khairanierica02@gmail.com \\ No BP:2010003600087 \\ Perguruan Tinggi:universitas eka sakti
}

\section{A. PENDAHULUAN}

Indonesia adalah negara hukum yang segala bentuk pemerintahan negara ini telah diatur dalam undang-undang dasar 1945, UUD' 45 menjadi tolak ukur segala hal mengenai harapan dan tujuan dari bangsa Indonesia. Pada undang-undang ' 45 alinea ke-4 menyatakan tujuan nasional negara Indonesia ialah untuk melindungi segenap bangsa Indonesia dan seluruh tumpah darah Indonesia dan untuk memajukan kesejahteraan umum, mencerdaskan kehidupan bangsa, dan ikut melaksanakan ketertiban dunia yang berdasarkan kemerdekaan, perdamaian abadi, dan keadilan sosial. Dapat dijelaskan bahwa negara Indonesia ingin mewujudkan keadilan sosial bagi seluruh rakyat Indonesia dan ini harus terwujud dalam kehidupan masyarakat. Penerapan tujuan nasional dalam rangka mewujudkan cita-cita bangsa Indonesia menuju masyarakat yang adil dan makmur berdasarkan Pancasila dan UUD'45, dengan adanya pembangunan nasional. Salah satunya adalah pembangunan manusia dalam bidang hukum, terutama hukum pidana. Pada pembangunan hukum pidana terdapat lembagalembaga yang menaungi yakni, kepolisian, kejaksaan,pengadilan, dan lembaga pemasyarakatan. Lembaga pemasyarakatan mempunyai peranan dalam pelaksanaan pembinaan bagi narapidana dan anak didik pemasyarakatan.Lembaga pemasyarakatan tidak hanya berfungsi sebagai penjeraan bagi narapidana namun merupakan tempat rehabilitasi dan reintegrasi sosial warga binaan

pemasyrakatan yang dilaksanakan secara terpadu antara pembina, yang dibina, dan masyarakat untuk meningkatkan kualitas warga binaan pemasyarakatan agar menyadari kesalahannya, memperbaiki diri, dan tidak mengulangi tindak pidana di masa yang akan datang. Pemasyarakatan merupakan bagian akhir dari sistem pemidanaan dalam peradilan pidana, dan merupakan bagian yang tidak terpisahkan dari rangkaian proses penegakan hukum.

\section{B PEMBAHASAN}

Indonesia adalah negara hukum bermaksud bahwa walaupun rakyat memegang kekuasaan tertinggi terhadap negara, namun tetap dibatasi oleh adanya hukum. Indoneisa adalah suatu negara yang memiliki dua sistem kedaulatan, yaitu sebagai negara kedaulatan rakyat dan negara kedaulatan hukum. Kedua sistem kedaulatan di Indonesia ini tecantum dalam UUD Negara Indonesia yaitu pada pasal-pasal berikut ini :Pasal 1 ayat (2) 
Pasal 1 ayat (2) berbunyi "Kedaulatan berada di tangan rakyat dan dilaksanakan menurut Undang-Undang Dasar". Hal ini adalah membuktikan bahwa Indonesia adalah negara dengan kedaulatan rakyat dimana kkuasaan tertinggi di tangan rakyat, namun rakyat tidak boleh melenceng dari Undang-Undang Dasar. Secara tidak langsung, ini digunakan agar tidak terjadinya ketimpangan antara hak dan kewajiban, dimana akan menuntut hak tanpa melaksanakan kewajiban.

Pasal 1 ayat (3)

Pasal 1 ayat (3) berbunyi "Negara Indonesia adalah negara hukum". Hal ini berarti bahwa Indonesia juga merupakan negara kedaultan hukum dimana rakyat di Indonesia melaksanakan kewajibannya terhadap negara dengan menaati hukum yang berlaku. Hal ini dikarenakan tidak ada hukum yang akan melenceng dari Undang-Undang Dasar.

Menurut Ust Rahmat Rizky Kurniawan SEI. MM,,Negara Indonesia berdasarkan atas hukum(rechtssaat) tidak berdasarkan kekuasaan belaka(machtssaat)artinya di sini,negara dan segenap unsur pemerintahannya dalam menjalankan pemerintahan,haruslah mengacu dan berpedoman atas kaidah-kaidah hukum,yang secara substansial di bentuk bukan dengan dasar kepentingan-kepentingan lain,melainkan untuk kepen tingan bangsa,negara dan rakyat.

Dan pernyataannya mengandung arti bahwa negara termasuk didalamnya pemerintah dan lembaga lembaga-lembaga yang lain, dalam melaksanakan tindakannya harus dilandasi oleh hukum atau dapat dipertanggungjawabkan secara hukum, semua berdasarkan pada aturan atau sesuai dengan hukum yang berlaku. Jika ada seseorang yang melakukan tindakan melanggar aturan, maka ia berhak untuk mendapatkan suatu hukuman karena dianggap melanggar hukum. seperti yang kita ketahui Indonesia adalah negara hukum, dan UUD 1945 adalah hukum tertinggi di Indonesia.

hal ini semakin diperjelas dalam UUD 1945 pasal 1 ayat 3 yang berbunyi "Negara Indonesia adalah negara hukum "Hal ini semakin mempertegas kepada seluruh masyarakat bahwa Indonesia adalah negara hukum, sehingga rakyat wajib untuk mentaati aturan yang berlaku. Sesuai dengan pembukaan UUD 1945, di sini negara hukum yang di maksud bukanlah sekedar negara hukum dalam arti formal, apalagi bukanlah Negara hanya sebagai penjaga malam atau penjaga ketertiban yang menjaga jangan terjadi pelanggaran dan menindak para pelanggar hukum. pengertian negara hukum menurut UUD 1945 adalah negara hukum dalam arti luas yaitu negara hukum dalam arti material.

Dalam hal ini peranan negara bukan saja melindungi segenap bangsa Indonesia dan seluruh tumpah darah Indonesia tetapi juga harus memajukan kesejahteraan umum dan mencerdaskan kehidupan bangsa. berdasarkan semangat negara hukum dalam arti kata luas (material) itu, Setiap tindakan negara haruslah mempertimbangkan dua Kepentingan yaitu kegunaannya(doelmatugheid) dan dasar hukumnya(rechtmatigheid).Adapun ciri-ciri negara hukum yang sudah berlaku umum bagi negara yang berdasarkan kepada negara hukum tersebut antara lain:

a) adanya perlindungan dan pengakuan hak asasi manusia, 
b) adanya suatu peradilan yang bebas dan tidak memihak dan,

c) adanya asas legalitas.

hak asasi manusia merupakan dasar dan martabat manusia yang mengandung harkat dan martabat manusia dalam menemukan kemerdekaan,keadilan dan perdamaian dunia,oleh karena itu, dalam menjalankan hukum, kita tidak dapat mengabaikan hak asasi manusia, malah kita di sini berkewajiban untuk melindungi dan menghormati hak asasi tersebut. Oleh karena itu kita berhak mencegah tindakan dan perlakuan sewenang-wenang baik itu yang di lakukan oleh pejabat ataupun masyarakat,karena di dalam penjelasan UUD 1945 menjelaskan dengan tegas bahwa negara Indonesia berdasarkan atas negara hukum (Rechtstaat), tidak berdasarkan kekuasaan (machstaat).

Dari Pernyataan diatas dapat diketahui bahwa semua orang berhak untuk memperoleh jaminan agar hukum dan negara harus di laksanakan dengan adil dan jujur, serta tidak memandang jabatan. Banyak kita temukan sekarang para pejabat yang korupsi memakan uang rakyat di berlakukan dengan sangat layak di penjara,sedangkan nenek tua yang di tuduh mencuri kayu di masukkan penjara dan di suruh bayar denda dengan jumlah yang sangat besar.dari pernyataan di atas dapat di ketahui bahwa setiap orang berhak untuk memperoleh jaminan agar hukum dan negara harus di laksanakan dengan adil dan jujur serta tidak meninggalkan rasa hormat akan harkat dan martabatnya,sebab semua orang berhak dapat keadilan, entah itu dia kaya, miskin, jabatannya tinggi atau tidak punya jabatan sama sekali.

Selanjutnya menurut ketentuan hukum yang berlaku di Indonesia, bahwa setiap insan atau warga yang hidup di negara hukum di wilayah republik Indonesia yang berdasarkan pancasila dan undang-undang dasar negara tahun 1945 mempunyai hak yang sama untuk mendapatkan bantuan hukum dan perlindungan hukum, jika ia terlibat dalam suatu perkara yang sengaja dilakukan atau suatu persoalan tindak pidana yang di tuduhkan kepadanya,terdapat dalam pasal 56 KUHP yang berbunyi:

1.Dalam hal tersangka atau terdakwa disangka atau didakwa melakukan tindakan pidana yang di ancam pidana mati atau ancaman pidana 15 tahun penjara atau lebih atau bagi orang yang tidak mampu yang diancam dengan 15 tahun penjara atau lebih yang tidak mempunyai penasehat hukum sendiri jabat yang bersangkutan pada semua tingkat pemeriksaan dalam proses peradilan wajib menunjuk penasehat hukum bagi mereka.

Pemberian bantuan hukum bagi masyarakat tersangka atau terdakwa, sangatlah penting karena sebagai warga negara dan warga masyarakat dapat saja terkena masalah. Menjadi tersangka atau terdakwa sebagai orang yang memerlukan kedudukan dan perlindungan di muka hukum(equality before the law) maka tersangka /terdakwa sebagai subjek hukum yang memiliki kesamaan perhatian dalam penanganan perkara yang sedang di hadapi

"Negara" bisa dimaknai dalam dua arti. Pertama, Negara adalah masyarakat atau wilayah yang merupakan satu kesatuan politis. Kedua, Negara adalah lembaga pusat yang menjamin 
kesatuan politis ,yang menata dan dengan demikian menguasai wilayah itu. Hukum sebagai sarana untuk melakukan kontrol sosial, yaitu suatu proses memengaruhi orang-orang untuk untuk bertingkah laku sesuai dengan harapan masyarakat. Maka pengontrolan oleh hukum itu dijalankan dengan berbagai cara dan melalui penbentukan badan-badanyang dibutuhkan.Dalam hubungan ini, maka hukum biasa disebut sebagai suatu sarana untuk melakukan kontrol sosial yang bersifat formal.

Menurut Brian Z.Tamanaha ,Negara hukum itu berkisar pada tiga kelompok pengertian (cluter of meaning).yaitu :

1. Bahwa pemerintah itu dibatasi oleh hukum. Dalam pemahaman yang pertama ini ,Negara hukum melindungi masyarakat dari penekanan (oppression) oleh pemerintah, baik yang bersifat komunitarian maupun individual. Ia juga melindungi masyarakat dalam keadaan pluralism.Khususnya bagi Negara-negara berkembang,seperti Indonesia ,Negara hukum akan melindungi masyarakat dari transformasi suatu tipe barat ke dalam masyarakat timur, yang memiliki kosmologi yang berbeda.

2. Negara hukum dipahami secara legalitas formal.Di sini ia dipahami sebagai sesuatu yang sangat bernilai (supremely valuable good), tetapi belum tentu memiliki nilai kemanusiaan yang bersifat universal (universal human good)pula. Di sini orang tidak dapat berpikir bahwa peraturan sebagai inti dari legalitas formal,berlaku untuk segala keadaan.Legalitas formal berjalan baik pada ranah kehidupan sosial, dimana dijumpai keadaan yang netral, seperti perdagangan,penghukuman terhadap orang yang melakukan kekerasan criminal dan terhadap orang yang mengganggu kepemilikan orang lain.

3. Pengaturan yang didasarkan pada hukum (rule of law), bukan orang (rule of man). Menurut Tamahana, keadaan tersebut dapat dicapai manakala dapat dicapai keseimbangan antara keduanya,yang intinya adalah pengendalian diri (self-restraint).

\section{PENUTUP}

Negara Indonesia adalah Negara hukum, begitu yang dinyatakan dalam UUD Negara Republik Indonesia 1945 pasal 1 ayat (3) yang dirumuskan dalam amandemennya yang ketiga ,Agustus 2011 yang lalu. Sehingga seharusnya seluruh sendi kehidupan dalam bermasyarakat dan bernegara harus berdasarkan pada norma-norma hukum. Artinya hukum harus dijadikan panglima dalam penyelesaian masalah-masalah yang berkenaan dengan individu ,masyarakat dan Negara.

Norma hukum bukanlah satu-satunya kaidah yang bersifat regulatif (mengatur) terhadap manusia dalam hubungannya dengan sesama manusia. Disamping norma hukum,ada norma sosial, kesusilaan dan agama .Ketiga norma (kaedah) terakhir memiliki aturan sanksi yang lunak jika dibandingkan dengan aturan sanksi pada norma hukum yang keras, sebab hukum memiliki alat perlengkapan yaitu Negara.

Hukum dipandang sebagai sesuatu yang luas,besar, dan agung. Hukum tidak dibuat tetapi hidup,tumbuh, dan berkembang bersama masyarakat. Walaupun pada kenyataannya hukum merupakan produk politik dimana hukum tergantung pada konfigurasi politik yang sedang berlangsung seperti yang dikatakan oleh Mahfud MD, namun seharusnya hukum harus tetap 
memuat nilai-nilai ideal yang harus dijunjung tinggi dan ditegakkan oleh segenap elemen masyarakat.

Kepongahan hukum semakin nyata di Indonesia. Kasus suap yang melanda mahkamah agung, Kasus Suyitno Landung dalam pemeriksaan perkara pembobolan bank BNI,menjadi pertanda jatuhnya wibawa hukum di mata masyarakat Indonesia. Kasus lain yang menggegerkan adalah tertangkap basahnya Jaksa Urip Tri Gunawan (kasus BLBI) yang kemudian seperti menghancurkan kewibawaan kejaksaan agung. Salah satu yang memberikan kontribusi bagi kebobrokan moral penegak hukum tersebut bisa jadi adalah pendidikan hukum. Pendidikan hukum selama ini hanya menyentuh pada tataran teoritik belaka, mengabaikan aspek moral. Sehingga dengan demikian Indonesia hanya mencetak "tukang-tukang hukum" bukan sarjana hukum dalam pengertian yang sebenarnya. Padahal semestinya pendidikan hukum kita bisa menciptakan seorang ahli hukum yang berdedikasi dan bukan ahli hukum yang "jualan hukum".

Adapun yang ingin dimintakan perhatian di sini yaitu, hendaknya kita juga meninjau perkembangan hukum di Indonesia semenjak penjajahan sebagai pembelajaran untuk masa sekarang dan yang akan datang. Terutama untuk menghadapi masalah yang sudah pernah terselesaikan di masa lampau, seperti korupsi. Banyak hal yang harus dilakukan untuk mencapai Tujuan dan cita-cita Indonesia sebagai Negara hukum agar 'negara hukum' tidak sekedar menjadi slogan kaku yang tidak bisa di realisasikan.

\section{DAFTAR PUSTAKA}

Darmini Roza dan Laurensius Arliman S Peran Pemerintah Daerah Di Dalam Melindungi Hak Anak Di Indonesia, Masalah-Masalah Hukum, Volume 47, Nomor 1, 2018.

Laurensius Arliman S, Komnas HAM dan Perlindungan Anak Pelaku Tindak Pidana, Deepublish, Yogyakarta, 2015.

Laurensius Arliman S, Penguatan Perlindungan Anak Dari Tindakan Human Trafficking Di Daerah Perbatasan Indonesia, Jurnal Selat, Volume 4, Nomor 1, 2016.

Laurensius Arliman S, Problematika Dan Solusi Pemenuhan Perlindungan Hak Anak Sebagai Tersangka Tindak Pidana Di Satlantas Polresta Pariaman, Justicia Islamica, Volume 13, Nomor 2, 2016.

Laurensius Arliman S, Pelaksanaan Perlindungan Anak Yang Tereksploitasi Secara Ekonomi Oleh Pemerintah Kota Padang, Veritas et Justitia, Volume 2, Nomor 1, 2016. 
Laurensius Arliman S, Kedudukan Ketetapan MPR Dalam Hierarki Peraturan PerundangUndangan Di Indonesia, Lex Jurnalica, Volume 13, Nomor 3, 2016.

Laurensius Arliman S, Komnas Perempuan Sebagai State Auxialiary Bodies Dalam Penegakan Ham Perempuan Indonesia, Justicia Islamica, Volume 14, Nomor 2, 2017.

Laurensius Arliman S, Peranan Pers Untuk Mewujudkan Perlindungan Anak Berkelanjutan Di Indonesia, Jurnal Ilmu Hukum Tambun Bungai, Volume 2, Nomor 2, 2017.

Laurensius Arliman S, Mewujudkan Penegakan Hukum Yang Baik Untuk Mewujudkan Indonesia Sebagai Negara Hukum, Jurnal Hukum Doctrinal, Volume 2, Nomor 2, 2017.

Laurensius Arliman S, Participation Non-Governmental Organization In Protecting Child Rights In The Area Of Social Conflict, The 1st Ushuluddin and Islamic Thought International Conference (Usicon), Volume 1, 2017.

Laurensius Arliman S, Partisipasi Masyarakat Dalam Pembentukan Perundang-Undangan Untuk Mewujudkan Negara Kesejahteraan Indonesia, Jurnal Politik Pemerintahan Dharma Praja, Volume 10, Nomor 1, 2017, https://doi.org/10.33701/jppdp.v10i1.379.

Laurensius Arliman S, Peran Komisi Perlindungan Anak Indonesia Untuk Mewujudkan Perlindungan Anak, Jurnal Respublica Volume 17, Nomor 2, 2018.

Laurensius Arliman S, Menjerat Pelaku Penyuruh Pengrusakan Barang Milik Orang Lain Dengan Mempertimbangkan Asas Fungsi Sosial, Jurnal Gagasan Hukum, Volume 1, Nomor 1, 2019.

Laurensius Arliman S, IImu Perundang-Undangan Yang Baik Untuk Negara Indonesia, Deepublish, Yogyakarta, 2019.

Laurensius Arliman S, Isdal Veri, Gustiwarni, Elfitrayenti, Ade Sakurawati, Yasri, Pengaruh Karakteristik Individu, Perlindungan Hak Perempuan Terhadap Kualitas Pelayanan Komnas Perempuan Dengan Kompetensi Sumber Daya Manusia Sebagai Variabel Mediasi, Jurnal Menara Ekonomi: Penelitian dan Kajian IImiah Bidang Ekonomi, Volume 6, Nomor 2, 2020.

Laurensius Arliman S, Pendidikan Kewarganegaraan, Deepublish, Yogyakarta, 2020. 
Laurensius Arliman S, Makna Keuangan Negara Dalam Pasal Pasal 23 E Undang-Undang Dasar 1945, Jurnal Lex Librum, Volume 6, Nomor 2 Juni 2020, http://dx.doi.org/10.46839/lljih.v6i2.151.

Laurensius Arliman S, Kedudukan Lembaga Negara Independen Di Indonesia Untuk Mencapai Tujuan Negara Hukum, Kertha Semaya Journal Ilmu Hukum, Volume 8, Nomor 7, 2020.

Laurensius Arliman S, Pelaksanaan Assesment Oleh Polres Kepulauan Mentawai Sebagai Bentuk Pelaksanaan Rehabilitasi Bagi Pecandu Dan Korban Penyalahgunaan Narkotika, Jurnal Muhakkamah, Volume 5, Nomor 1, 2020.

Laurensius Arliman S, Aswandi Aswandi, Firgi Nurdiansyah, Laxmy Defilah, Nova Sari Yudistia, Ni Putu Eka, Viona Putri, Zakia Zakia, Ernita Arief, Prinsip, Mekanisme Dan Bentuk Pelayanan Informasi Kepada Publik Oleh Direktorat Jenderal Pajak, Volume 17, No Nomor, 2020.

Larensius Arliman S, Koordinasi PT. Pegadaian (Persero) Dengan Direktorat Reserse Narkoba Polda Sumbar Dalam Penimbangan Barang Bukti Penyalahgunaan Narkotika, UIR Law Review, Volume 4, Nomor 2, 2020, https://doi.org/10.25299/uirlrev.2020.vol4(1).3779.

Laurensius Arliman S, Tantangan Pendidikan Kewarganegaraan Pada Revolusi 4.0, Ensiklopedia Sosial Review, Volume 2, Nomor 3, 2020.

Muhammad Afif dan Laurensius Arliman S, Protection Of Children's Rights Of The Islamic And Constitutional Law Perspective Of The Republic Of Indonesia, Proceeding: Internasional Conference On Humanity, Law And Sharia (Ichlash), Volume 1, Nomor 2, 2020.

Otong Rosadi danLaurensius Arliman S, Urgensi Pengaturan Badan Pembinaan Idelogi Pancasila Berdasarkan Undang-Undang Sebagai State Auxiliary Bodies yang Merawat Pancasila dalam Perspektif Hak Asasi Manusia, Prosiding Konferensi Nasional Hak Asasi Manusia, Kebudayaan dan Tujuan Pembangunan Berkelanjutan Indonesia pada Masa Pandemi Covid-19: Tantangan untuk Keilmuan Hukum dan Sosial Volume 1, Universitas Pancasila, Jakarta, 2020 